\title{
Corporate Philanthropic Giving: Active Responsibility Or Passive Ingratiation? Evidence From Chinese Family-Controlled Listed Companies
}

Junrui Zhang, Xi'an Jiaotong University, China Bei Yang, Xi'an Jiaotong University, China

Fangjun Wang, Xi'an Jiaotong University, China

Peng Wang, Xi'an International Studies University, China

\begin{abstract}
This paper examines the impact of political connection on family-controlled listed firms' philanthropic giving activities toward the 2008 Wenchuan Earthquake in China, and stock price reactions to such activities. Using the 542 Chinese listed companies controlled by private owners as the sample, it was found that firms with political connection are more likely to donate. Besides, focusing on the 244 donating firms, it was found that there is a positive impact of the donation amount on stock price response. What's more, the positive stock price reactions toward the donation announcement made by firms with political connection are not as strong as that of firms without such connection. Regression results indicate that although family-controlled firms with political connection are more likely to donate, their activities can not generate as much positive stock price effect as their no-political connection counterparts. These results reveal that both political interferences and market mechanisms have critical impact on corporate philanthropic behavior in China.
\end{abstract}

Keywords: Corporate Philanthropy; Political Connection; Political Interference; Market Mechanism

\section{INTRODUCTION}

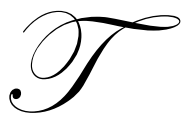

he purpose of this research is to investigate the relation between political connection and philanthropic giving activities in family-controlled listed companies, the underlying motivations and investors' reactions to such behaviors under the context of China. In the past few years, China has witnessed a rapid economic growth since the implementation of the reform and openness policy. The economic system was gradually transformed from planned economy to market economy. It means that the development of the economy is mainly motivated by market competition other than the government planning. However, till now, the Chinese government still intervene the economic system greatly. Therefore, the government grasps many resources and determines the resource allocation in the market. To improve the operating competitiveness, many companies seek to establish connection with the government so as to acquire additional resources. Liu, Wang and Wu (2011) point out that the political connection has been one of the major factors that might determine business success. In fact, the political connection has become a primary channel to acquire resources and support (Hwang et al., 2009). To obtain resources and support from political connection, companies would be more likely to follow the government's requirements. Therefore, companies tend to actively ingratiate themselves with the government and implement the social responsibility, especially when some events happen. The philanthropic activity is a typical form companies implement social responsibilities when some catastrophic events happen. Therefore, the companies with political connection are more likely to donate to reflect their loyalty. 
Compared to companies controlled by government, family-controlled listed companies are under less intervention from the government and the decision could be made more independently. However, the entrepreneurs of the family-controlled companies always establish connection with government in order to capture support from the government. Underlying this specific institutional background in China, this paper aims to examine the impact of political connection on the family-controlled listed companies' philanthropic donation, and whether such philanthropic activities could be appreciated by the market.

Our results show that companies with political connection tend to meet the governmental requirements and are more likely to donate for the earthquake. It is also found that such philanthropic giving activities generate a positive market reaction. What's more, the philanthropic giving activities made by family-controlled listed companies without political connection are more valued by investors than that in companies with political connection.

This paper contributes to the literature in three aspects. For one thing, extant literatures on the determinants of corporate philanthropic activities mainly focus on firm-level factors, such as ownership structure and accounting information. However, in Chinese stock market, the orientation of the government is an important factor in firms' decision-making, especially in the face of tragedies. Gao (2011) studied the relations between political connection and philanthropic giving, among both SOEs and non-SOEs. However, SOEs and non-SOEs have distinct features, that is, SOEs have multiple objectives, while non-SOEs are more concentrated on the pursuit of profits. Considering the difference in the objectives between SOEs and non-SOEs, this paper focuses on family firms' philanthropic activities, because it will show us a clearer picture of the firms' incentives to donate.

Besides, considering the fact that family-controlled firms tend to actively establish political connections to the government to obtain potential benefits, it is meaningful to compare the impact of political connection on the family-controlled firm's philanthropic behaviors. And we do find that family-controlled firms with political connections are more likely to donate than those without such connections.

Lastly, no consistent conclusion was reached in the economic consequence of firms' announcement on philanthropic activities. Although no significant relation between philanthropy and market value was found in Seifert, Morris and Bartkus (2003), Patten (2008) found that donation can bring about significant and positive stock price reactions. Focusing on family-controlled firms that make donations during the Wenchuan Earthquake, this paper not only reached similar conclusions to Patten (2008), but also find the asymmetric reactions among investors toward the announcement of corporate donations. Specifically, compared with firms without political connection, firms with such connection receive less positive market reactions, on the announcement of philanthropic giving.

The rest of this paper is organized as follows. The next section briefly introduces the background on the earthquake; section three constructs the theoretical framework on the philanthropic giving and review the literatures on the determinants of philanthropic giving; hypothesis development is in section four and section five shows the research design; in section six, we list the regression results and we further investigate the market reaction to the philanthropic giving in section 7. Conclusions are reached at the last section.

\section{THE GREAT WENCHUAN EARTHQUAKE AND GOVERNMENTAL BEHAVIOR}

In 2008, a horrible earthquake happened in Wenchuan, a city in the southwest of China. Tens of thousands of lives were lost and survivors in that city became homeless. The government and army tried their best to aid the citizens there. At the same time, the government called on people around the country to support the survivors and reconstruct the places damaged in the earthquake. For example, the Communist Party of China required that all the members should donate a specific amount as the Special Party Membership Dues. In fact, many corporate and institutions voluntarily donated to the damaged areas in that year. Therefore, the corporate philanthropic giving activities increased dramatically in 2008. What motivates the corporate to engage in the philanthropic giving? Do the family-controlled listed firms that make philanthropic giving follow their heart, or just cater to the requirements from the government? These questions will be examined in the following sections. 


\section{THEORETICAL FRAMEWORK AND LITERATURE REVIEW}

\section{Theoretical Framework}

Corporate philanthropic giving has been studied by numerous scholars, with each study focusing on a certain aspect of the issue. Based on theories, including the agency theory, the resource dependency theory, the stakeholder theory and legitimacy, we tried to construct a comprehensive theoretical framework to explain the determinants, the motivation and economic consequence of corporate philanthropic giving (See figure 1).

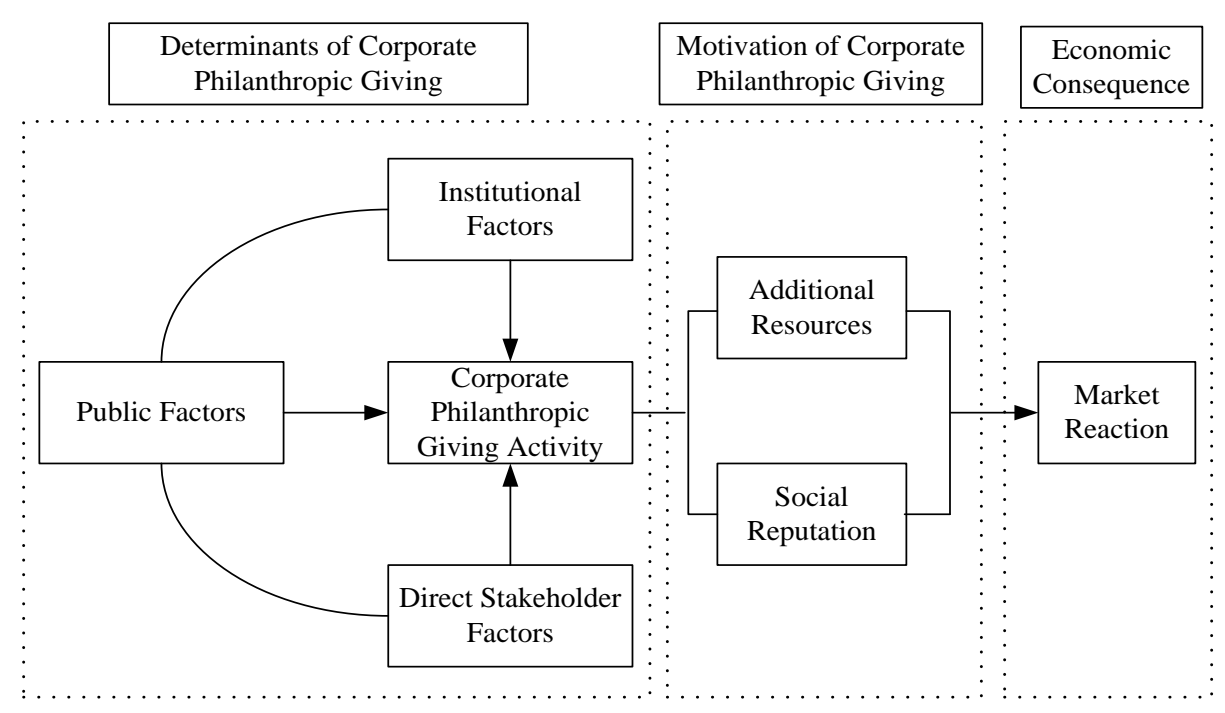

Figure 1: Framework on the Corporate Philanthropic Giving

The corporate is an important part of the society, and its activities are constrained by a series of social contracts (Cullinan et al., 2008; Neill, 2005; Hess and Warren, 2008; Zhang et al. 2010; Gao, 2011), including the formal and informal institutions. For example, political connection is common in many developing countries, such as China and Malaysia (Wahab et al., 2005; Gul, 2006). If the management holds a position in the government, his behavior would be affected by the government. In addition to the institutional factors, the corporate is also regulated by the public (Oliver, 1991). This regulation, such as large firm size (Brammer and Millington, 2006; Zhang, Rezaee and Zhu, 2009), and operating in a sensitive industry (Useem, 1998; Gao, 2011), increases the corporates' propensity to donate when a disaster happened. From the stakeholder theory, the corporate behavior is determined by stakeholders, and will affect the stakeholders' interests. Why do the corporate engage in philanthropic giving activity? There are mainly two motivations. First, philanthropic giving could maintain the political connection and increase the additional resource available (Buchholtz, Amason and Rutherford, 1999), such as the tax relief, policy support and government bailout, etc. Second, the social reputation would increase with the corporates' philanthropic giving activity (Burt, 1983). These two aspects are good news for the corporate. And thus, the market will react positively (Gardberg and Fombrun, 2006). Therefore, corporate have the motivation to donate when a serious disaster happen.

\section{Determinants of Philanthropic Giving Activities}

Many scholars have focused on the determinants of philanthropic activities. These determinants can be classified into three categories, based on our theoretical framework. 
Firstly, from the perspective of public and consumer effect, the management wants to gain advertising effects to enhance social image through philanthropic activities (Porter and Kramer, 2002). Therefore, companies with large advertising spending often donate more to achieve the effect of advertising (Navarro, 1988). Brown, Helland and Smith (2006) found that corporate donations and advertising expenditure show a positive correlation in a regulated industry, and companies with high R\&D investment donated more than others. Amato and Amato (2007) also found that the type of industry significantly affected corporate donations. Donation is more effective when promoting products of no practical use, and the interaction between products features and the amount of contributions jointly determines the effectiveness of charitable motivation to promotion (Strahilevitz and Myers, 1998; Strahilevitz, 1999). Corporate in the service sector will donate more than other industrial firms (Gao, 2011), which is due to the fact that firms in service sector or some other industry depend more on public support (Clotfelter, 1985).

In addition, firms with different size or profitability also give different amount of donation (Adams and Hardwick, 1998), which may result from the different level of public effect between larger and smaller firms. Larger firms, being more attractive to the public, tend to donate more in order to keep and increase their public reputation (Brammer and Millington, 2006). Similarly, Adams and Hardwick (1998) found that the level of donations is positively related to company size and profitability using data drawn from 100 UK listed companies. However, instead of the linear relationship, Amato and Amato (2007) found that there was a U-shaped relation, that is, when the company size is relatively small or large, donation rate is high; and when the size of the company is close to the average level, the donation rate significantly decreases.

Meanwhile, some scholars believe that institutional factors may also affect the behavior of corporate donations. Phenomena like too much donation or absolutely no donation are the results of social mechanisms, and tax policy also plays an important role in corporate giving (Clotfelter, 1985; Boatsman and Gupta, 1996; Carroll and Joulfaian, 2005). Thus, charitable organizations can increase the transparency of donations by classifying the amount of contributions or introducing open donation, thereby increasing the amount of donation (Harbaugh, 1998). Based on the data of Chinese listed companies, Gao (2011) also found that corporate with political connection always donate more than others due to the greater government pressures.

In China, the government plays a particularly important role in the process of promoting the economic development and has a significant impact on corporate activities. Corporate social behavior not only reflects selfworth, but also reflects government wishes. Government plays a dominant role in the allocation of resources so that companies with good political connection will have the advantage of access to resources. In this case, many family enterprises with government backgrounds are actively seeking the opportunity to establish friendly relations with the government by responding positively to the government's call to support the government's donation. So, it can be expected that in this particular market environment in China, firms with political connection are more willing to donate in the consideration of achieving resource advantage in future.

In addition to the public and institutional factors, the stakeholders are also an important determinant of philanthropic giving. It is well known that there is interest conflict between the principal and the agent, including the management and shareholder, debtor and creditor, majority shareholders and minority shareholders, so the final philanthropic activities is the result of the game between different stakeholders. Firms with high financial leverage always give less to charity than others (Brown, Helland and Smith, 2006; Adams and Hardwick, 1998) in that they are facing higher pressure from the creditor. Brown, Helland and Smith (2006) also found that board size was proportional to the amount of corporate donations. Similarly, Atkinson and Galaskiewicz (1988) found that CEO's ownership percentage significantly affected the amount donated. When the CEO has a larger proportion of the company's shares or equity is relatively concentrated, the amount donated is usually lower and vice versa. Adams and Hardwick (1998) established the framework from the perspective of stakeholder theory, and testified that ownership structure plays an important role in philanthropic giving, similar conclusion can also be found in Zhang et al. (2009), Gao (2011) and other literatures. As corporate behavior is an equilibrium decision in a set of complicated contracts, which involves different goals and interests coming from different stakeholders (Neill and Stovall, 2005), the final donation activities may be more inclined to stakeholders who own more voting right. Therefore, the ownership structure may affect the amount donated through the distribution of right. 
Overall, the companies are faced with pressures from many parties, and there are different motivations for these parties to exert pressure on the companies. Therefore, these factors would influence the philanthropic giving activities.

\section{HYPOTHESIS DEVELOPMENT}

As a common phenomenon in the emerging market, especially in the East Asia, the political connection is always regarded as a way to acquire more resource. It is more apparent in China since the government dominates the allocation of resources. To obtain these privileges, the family firms have to establish political connection with the government. Therefore, they tend to be more actively involved in supporting national policy and catering to the government requirements in order to achieve resource or other advantage in future. Meanwhile, the familycontrolled listed companies always face with the pressure from government due to political connection. For example, if the founder of the company holds a post in the National People's Congress (NPC), the company would benefit from this post since it means more power and resources. However, the founder should strive to maintain this post. The post of the member in NPC would be removed if he could not follow the government. Therefore, the companies with political connection always take on some social responsibility activities following the instruction from the government when some catastrophic events, such as earthquakes, floods and other serious disasters happen. Therefore, compared with other family companies, based on the consideration of alleviating political pressure and acquiring additional political resources, family companies with political connections are more likely to take on philanthropic giving activities. Based on the above analysis, we propose the following hypothesis:

\section{H: Family-controlled listed companies with political connection are more likely to donate than that without political connection.}

\section{RESEARCH DESIGN}

\section{Sample Selection and Data Source}

Using the family-controlled listed companies of Shanghai Stock Exchange and Shenzhen Stock Exchange in 2008 as the sample, 571 companies are selected. Then we excluded 29 companies whose gearing ratios were greater than 1 based on the consideration of prudence. And finally we have 542 companies as the research sample. After downloading annual reports and interim reports of board resolution of those sample companies from www.cninfo.com.cn which was designated by the China Securities Regulatory Commission, we carefully read those reports and sorted out the amount donated in Wenchuan Earthquake and total annual contributions. Other financial data are from the CSMAR database.

\section{Measurement of Variables}

The indicator variable of corporate donation in Wenchuan Earthquake (DonDum). It is coded 1 if the company donated in Wenchuan Earthquake; and 0 otherwise.

The amount of corporate donations in Wenchuan Earthquake (LnDon). The natural logarithm of the amount of donations in Wenchuan Earthquake.

This paper focuses on whether companies with political connection are more likely to donate, so we select the variable measuring political connection (PolCon). It takes the value of 1 if the firm is with political connection and 0 otherwise.

We select the company size (Size), return on assets $(R O A)$, the proportion of independent directors on board (IndPer), the shares owned by the largest shareholder (OwnCon), regulated industry (Indus), leverage (Lev) and cross-listing (Cross) as control variables. The definitions of the variables are listed in Table 1. 
Table 1: Variables And Definitions

\begin{tabular}{|c|c|}
\hline Panel A & Variables used in Model 1 \\
\hline Variables & Definitions \\
\hline DonDum & Dummy variable, coded 1 if the company donated during the Great Wenchuan Earthquake; 0 otherwise. \\
\hline PolCon & Dummy variable, coded 1 if a company has political connection; 0 otherwise. \\
\hline Size & The natural logarithm of total assets. \\
\hline$R O A$ & Return on assets. \\
\hline Indus & $\begin{array}{l}\text { Dummy variable, coded } 1 \text { if the firm is operating in highly regulated industry (such as the public service } \\
\text { industry, mining industry, electricity, gas and water production). }\end{array}$ \\
\hline Cross & Dummy variable, coded 1 if shares are also listed as B shares or $\mathrm{H}$ shares, 0 otherwise. \\
\hline IndPer & The ratio of the number of independent directors to the total number of directors. \\
\hline OwnCon & The percentage of shares owned by the largest shareholder. \\
\hline Lev & The ratio of debt to total assets of the company. \\
\hline Panel B & Variables used in Model 2 and Model 3 \\
\hline Variables & Definitions \\
\hline LnDon & The natural logarithm of the amount of donations in Wenchuan Earthquake. \\
\hline CAR & $\begin{array}{l}\text { The market reaction to the announcement of philanthropic giving, is the cumulative abonormal return during day } \\
0 \text { and day }+1 \text {. }\end{array}$ \\
\hline SpeTre & $\begin{array}{l}\text { Dummy variable, coded } 1 \text { if ST-company, *ST-company or PT-company has been changed to normal company, } \\
\text { or *ST-company and PT-company has been changed to ST-company during the reporting period, and } 0 \\
\text { otherwise. }\end{array}$ \\
\hline \multirow[t]{2}{*}{ DisCre } & $\begin{array}{l}\text { The discrepancy of ultimate owner's the voting right and cash flow right, calculated as: } \\
\text { Voting Right - Cash Flow Right }\end{array}$ \\
\hline & 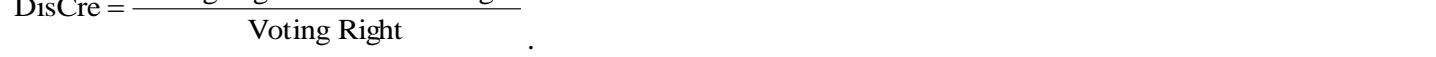 \\
\hline BorCom & Dummy variable, coded 1 if there are complete board committees, 0 otherwise. \\
\hline Dual & Dummy variable, coded 1 if the chairman of board and CEO are the same person, 0 otherwise. \\
\hline Region & $\begin{array}{l}\text { Dummy variable, coded } 1 \text { if the company located is in the developed provinces including Shanghai, Peking, } \\
\text { Tianjin, Zhejiang, Jiangsu and Guangdong, and } 0 \text { otherwise. }\end{array}$ \\
\hline
\end{tabular}

\section{Model Construction}

To investigate the determinants of philanthropic giving, we construct the following model.

$$
\text { DonDum }=\beta_{0}+\beta_{1} \text { PolCon }+\beta_{2} \text { Size }+\beta_{3} \text { ROA }+\beta_{4} \text { Indus }+\beta_{5} \text { Cross }+\beta_{6} \text { IndPer }+\beta_{7} \text { OwnCon }+\beta_{8} \text { Lev }+\varepsilon
$$

\section{EMPIRICAL RESULTS ON THE IMPACT OF POLITICAL CONNECTION ON CORPORATE PHILANTHROPIC GIVING}

\section{Descriptive Statistics}

Table 2: Descriptive Statistics

\begin{tabular}{lccccccc}
\hline Variables & Minimum & Maximum & Mean & Median & Std. Deviation & Q1 & Q3 \\
\hline LnDon & 0.000 & 17.233 & 7.839 & 12.206 & 6.725 & 0.000 & 13.816 \\
DonDum & 0.000 & 1.000 & 0.581 & 1.000 & 0.494 & 0.000 & 1.000 \\
PolCon & 0.000 & 1.000 & 0.399 & 0.000 & 0.490 & 0.000 & 1.000 \\
Size & 15.560 & 24.531 & 20.881 & 20.860 & 1.062 & 20.199 & 21.553 \\
ROA & -1.032 & 1.268 & 0.039 & 0.038 & 0.136 & 0.011 & 0.079 \\
Indus & 0.000 & 1.000 & 0.287 & 0.000 & 0.453 & 0.000 & 1.000 \\
Cross & 0.000 & 1.000 & 0.033 & 0.000 & 0.180 & 0.000 & 0.000 \\
IndPer & 0.143 & 0.667 & 0.367 & 0.333 & 0.053 & 0.333 & 0.400 \\
OwnCon & 4.490 & 85.230 & 32.474 & 29.440 & 14.479 & 22.050 & 41.900 \\
Lev & 0.018 & 0.956 & 0.596 & 0.468 & 1.024 & 0.333 & 0.625 \\
\hline
\end{tabular}


Table 2 presents the descriptive statistics of main variables used in the models. It shows that the difference in the amount of donations between family-controlled listed companies is relatively large in the donations in Wenchuan Earthquake (The standard deviation is 6.725). There are companies which didn't make any contributions among the samples. The company which made the largest amount of contribution has a natural logarithm of 17.233 (Total amount of donation is RMB 30500000 ) and the natural logarithm of average contribution is 7.839. In sum, about $58.10 \%$ of the family-controlled listed companies have made donation during the Wenchuan Earthquake. Almost $40 \%$ of them have established political connection, indicating that the political connection between family companies and the government is a common phenomenon in China.

In addition, the logarithm of the average size of the samples is 20.881 , and the average return on total assets is $3.9 \%$, which shows that the profitability of family-controlled listed companies is relatively low. Only $3.3 \%$ of the companies have shares listed as B shares or $\mathrm{H}$ shares, representing that cross-listing of family-controlled companies is relatively rare. The average proportion of independent directors on board is $36.7 \%$, which shows that most companies are able to appoint a certain number of independent directors in the board so as to meet the minimum requirements of one-third of board members being independent directors. The average value of the shares owned by the largest shareholder is $32.474 \%$. The average leverage is $59.6 \%$, which shows that the average gearing ratio remains at a rational level.

\section{Correlation Analyses}

Table 3 lists the correlation matrix of the main variables used in Model 1. The indicator variable of corporate donations (DonDum) has a significantly positive correlation with political connection, the company size, the firm performance and the regulated industry. From the correlation coefficients among the variables, it can be seen that there is no serious multicollinearity problem.

Table 3: Correlations Matrix

\begin{tabular}{lccccccccc}
\hline Variables & DonDum & PolCon & Size & ROA & Indus & Cross & IndPer & OwnCon & Lev \\
\hline DonDum & 1.000 & $0.242^{* *}$ & $0.291^{* *}$ & $0.254^{* *}$ & $0.084^{*}$ & $-0.100^{*}$ & -0.053 & $0.117^{* *}$ & $-0.136^{* *}$ \\
PolCon & $0.242^{* *}$ & 1.000 & $0.114^{* *}$ & $0.091^{*}$ & -0.004 & -0.012 & 0.001 & 0.064 & -0.080 \\
Size & $0.309^{* *}$ & $0.135^{* *}$ & 1.000 & -0.020 & -0.001 & 0.026 & $-0.131^{* *}$ & 0.110 & $0.241^{* *}$ \\
ROA & $0.109^{* *}$ & 0.037 & 0.044 & 1.000 & 0.068 & $-0.142^{* *}$ & -0.063 & $0.206^{* *}$ & $-0.306^{* *}$ \\
Indus & $0.084^{*}$ & -0.004 & -0.017 & 0.068 & 1.000 & -0.031 & 0.017 & -0.064 & 0.028 \\
Cross & $-0.100^{*}$ & -0.012 & 0.044 & $-0.103^{*}$ & -0.031 & 1.000 & 0.032 & -0.058 & 0.056 \\
IndPer & -0.058 & -0.009 & $-0.119^{* *}$ & -0.001 & 0.021 & 0.011 & 1.000 & 0.017 & 0.011 \\
OwnCon & $0.103^{*}$ & 0.053 & $0.152^{* *}$ & $0.114^{* *}$ & -0.054 & -0.066 & 0.022 & 1.000 & -0.074 \\
Lev & $-0.148^{* *}$ & $-0.092^{*}$ & $-0.257^{* *}$ & $-0.348^{* *}$ & $0.094^{*}$ & $0.084^{*}$ & 0.028 & $-0.110^{* *}$ & 1.000 \\
\hline
\end{tabular}

Notes:

(1) The upper right triangle is Spearman's rank correlation coefficient and the bottom left triangle is Pearson correlation coefficient.

(2) $* *$ and $*$ indicate variable significance at the $1 \%$ and $5 \%$, respectively.

\section{Regression Results}

Table 4 presents logistic regression results of the impact of political connection on the family-controlled listed firm's decision to donate to the Wenchuan Earthquake. The coefficient on political connection (PolCon) is significantly positive (Coefficient $=0.920$, Wald-value $=21.657$ ), indicating that family-controlled listed companies with political connection are more likely to donate than those without political connection during the period of Wenchuan Earthquake. Thus, our hypothesis is supported. There are mainly two reasons to explain this relationship. First, to maintain the political connection, family-controlled listed companies would actively take on philanthropic activities. Second, these companies would benefit from the donation, e.g. the tax reduction, external resources or public reputation. 
Table 4: Logistic Regression Results on the relation between Political Connection and the Likelihood of Donation in Family-controlled listed Firms

\begin{tabular}{lccc}
\hline Variables & Coefficient & Wald & Sig. \\
\hline Constant & $-14.365^{* * *}$ & 34.829 & 0.000 \\
PolCon & $0.920^{* * *}$ & 21.657 & 0.000 \\
Size & $0.709^{* * *}$ & 41.663 & 0.000 \\
ROA & $1.608^{*}$ & 3.626 & 0.057 \\
Indus & $0.493^{* *}$ & 5.223 & 0.022 \\
Cross & $-1.472^{* *}$ & 6.069 & 0.014 \\
IndPer & -0.483 & 0.068 & 0.794 \\
OwnCon & 0.005 & 0.511 & 0.475 \\
Lev & $-1.133^{* * *}$ & 0.002 \\
-2 Log likelihood & 658.257 & 9.178 & \\
Cox \& Snell $R^{2}$ & 0.187 & & \\
Nagelkerke $R^{2}$ & 0.251 & &
\end{tabular}

Notes: $* * * * * * *$ indicate the correlation is significant at the $0.01,0.05$, and 0.10 levels, respectively.

In light of the control variables, the regression coefficient on corporate size (Size) is 0.709, and significant at the level of $1 \%$ which is consistent with results from previous studies (Boatsman and Gupta, 1996; Zhang, Rezaee and Zhu, 2009; Gao, 2011). The coefficient on firm performance (ROA) is significantly positive (Coefficient=1.608, Wald-value=3.626). The coefficient on the regulated industry (Indus) is 0.493 and significant at the level of $5 \%$. The results indicate that the family-controlled listed companies with large size, good performance and operating in regulated industries are more likely to donate. However, the coefficients on the percentage of independent director (IndPer) and the shares owned by the largest shareholder (OwnCon) are insignificant. The coefficient on leverage ( $L e v)$ is -1.133 and significant at the level of $1 \%$, indicating that there is a significant and negative correlation between the leverage and the likelihood to donate. The coefficient on the cross-listing is also significantly negative (Coefficient=-1.472, Wald-value=6.609), indicating that cross-listing companies are less likely to donate compared to other companies. It could be attributed to the more strict legislations and policies for cross-listing companies and higher level of protection of investors. Therefore, their donation activities might be under more constraints than other companies.

\section{SUPPLEMENT ANALYSIS: MARKET REACTION TO THE CORPORATE PHILANTHROPIC GIVING}

In this part, we intend to further test whether the family-controlled listed firms' philanthropic giving activities will be appreciated by investors. Some scholars argue that blockholders and institutional owners perceive philanthropic giving as excessive (Bartkus, Morris and Seifert, 2002), and could not necessarily improve firm value (Seifert, Morris \& Bartkus, 2003). Patten (2008) studied US listed firms' philanthropic giving toward the 2004 Tsunami in South Asia, and found that investors react positively to the announcement of donation. Unlike accounting information, philanthropic activities reflect the firm's willingness to fulfill its social responsibilities. And the amount of philanthropic giving can be regarded, to some extent, as the firm's contribution to the society. Therefore, we expect that Chinese family-controlled listed firms engaging in such activities will generate positive reactions among the investors. What's more, the higher the amount of philanthropic giving, the stronger will stock price reactions be. Thus, the following model is adopted, and it is expected that $\beta_{1}>0 .{ }^{1}$

$\begin{aligned} C A R_{(0,+1)}= & \beta_{0}+\beta_{1} \text { LnDon }+\beta_{2} \text { SpeTre }+\beta_{3} \text { DisCre }+\beta_{4} \text { BorCom }+\beta_{5} \text { ROA }+\beta_{6} \text { Size }+ \\ & \beta_{7} \text { Dual }+\beta_{8} \text { IndPer }+\beta_{9} \text { Region }+\varepsilon\end{aligned}$

(Model 2)

Considering the association between political connection and philanthropic giving activities, we also intend to test whether investors will react differently toward the philanthropic giving activities made by family-controlled

\footnotetext{
${ }^{1}$ See the appendix for the calculation of cumulative abnormal return.
} 
listed firms with political connection and those without such connection. In China, the majority of listed firms are ultimately controlled by the State. With the financial support from the government, these listed firms are less pressured in financing, especially when they are in face of bankruptcy. Besides, with the advantage to information and resources, firms with affiliation to government officers can enjoy more opportunity to expand their business. Therefore, privately owned firms can enjoy potential benefits from such affiliation, by establishing political connection with the government. Accordingly, these firms are more likely to respond to government policyorientation.

In the face of the giant loss in the Wenchuan Earthquake, the Chinese government called on both firms and individuals to donate money to the places which are seriously damaged. Although the donation activity is totally voluntary, the underlying incentives to donate between family firms with political connection and those without such connection may differ. This is because family firms with political connection can obtain potential benefits, and complying with the government's policy orientation and making philanthropic giving can maintain such political connections. On the other hand, those firms without political connection, facing with less political pressures, are more likely to donate because they really care about it. Therefore, investors may react asymmetrically toward the philanthropic giving announcements made by firms with political connection and those without such connection. By adding both political connection(PolCon), and the interaction term between the amount of donation(LnDon) and political connection(PolCon) to regression model 2, we expect that $\beta_{1}>0$ and $\beta_{3}<0$.

$$
\begin{aligned}
\text { CAR }(0,+1)= & \beta_{0}+\beta_{1} \text { LnDon }+\beta_{2} \text { PolCon }+\beta_{3} \text { PolCon } \times \text { LnDon }+\beta_{4} \text { SpeTre }+\beta_{5} \text { DisCre }+\beta_{6} \text { BorCom } \\
& +\beta_{7} \text { ROA }+\beta_{8} \text { SIZE }+\beta_{9} \text { Dual }+\beta_{10} \text { IndPer }+\beta_{11} \text { Region }+\varepsilon
\end{aligned}
$$

(Model 3)

After merging the donation announcement data with stock return data, the stock price reaction sample consists of 244 family-controlled listed firms. All the donation announcement data of family-controlled listed firms are hand-collected. And daily stock price data are collected from the CSMAR database.

Table 5: Regression Results for the Market Reactions to Philanthropic Giving

\begin{tabular}{lllll}
\hline \multirow{2}{*}{ Variables } & Column $\mathbf{1}(\mathbf{N = 2 4 4})$ & & Column $2(\boldsymbol{N}=\mathbf{2 4 4})$ \\
\cline { 2 - 5 } & Coefficients & $\boldsymbol{p}$ & Coefficients & $\boldsymbol{p}$ \\
\hline (Constant) & -0.095 & 0.312 & -0.132 & 0.158 \\
LnDon & $0.007^{* *}$ & 0.042 & $0.008^{* *}$ & 0.020 \\
PolCon & & & -0.011 & 0.150 \\
PolCon $\times$ LnDon & & & $-0.017^{* * *}$ & 0.005 \\
SpeTre & $0.034^{* *}$ & 0.016 & $0.036^{* *}$ & 0.010 \\
DisCre & $-0.004^{*}$ & 0.088 & $-0.005^{* *}$ & 0.049 \\
BorCom & $-0.022^{* *}$ & 0.025 & $-0.021^{* *}$ & 0.034 \\
ROA & 0.055 & 0.307 & 0.071 & 0.186 \\
Size & 0.002 & 0.749 & 0.003 & 0.548 \\
Dual & 0.004 & 0.667 & 0.004 & 0.629 \\
IndPer & -0.061 & 0.480 & -0.058 & 0.490 \\
Region & -0.005 & 0.518 & -0.001 & 0.856 \\
Adjusted $R^{2}$ & 0.058 & & 0.087 & \\
$F$ & 2.665 & & 3.105 & \\
\hline Notes: & & & \\
\hline
\end{tabular}

Notes:

(1) $* * *, * * * *$ indicate the correlation is significant at the $0.01,0.05$, and 0.10 levels, respectively.

(2) The dependent variable is $C A R$.

By regressing the cumulative abnormal returns during day 0 and day +1 on the amount of donation, it can be seen from Table 5 column 1 that the regression coefficient on LnDon is positive and significant at $5 \%$ level, indicating that corporates' philanthropic giving activities are valued by investors, and can generate positive abnormal returns, in accordance with our expectation. 
As is shown in column 2, the regression coefficient on $\operatorname{LnDON}$ is 0.008 , and significant at $5 \%$ level, while that on the interaction term between political connection dummy and donation amount (PolCon $\times$ LnDon $)$ is -0.017 , and significant at $1 \%$ level. Consistent with our expectation, although the impact of donation on stock returns is still positive, such positive effect of philanthropic giving on investors will be weakened by the presence of political connection. Thus, it seems that toward the news of philanthropic giving reported by firms with political connection, investors do not react as strongly as they react to the donation announcements initiated by firms without such connection.

\section{CONCLUSION}

As an important part of the society, companies not only seek the maximization of their interests, but also feedback to the society through engaging in philanthropic activities. Under the specific institutional background in China, this paper not only investigated what motivates the family-controlled listed companies to take on philanthropic giving, but also examined market reactions to the announcement of donation.

Using the sample of family-controlled listed companies in 2008 when the Great Wenchuan Earthquake happened, we find that the family-controlled listed companies with political connection are more likely to make donations. Therefore, the philanthropic giving activity is more likely to be motivated by the political pressure from the government.

Besides, we find that the corporate philanthropic giving activities are appreciated by investors, and can generate positive abnormal returns. What's more, the market reactions to the announcement of philanthropic giving are less positive in firms with political connection than those without political connection. These results indicate that compared with firms with political connection, philanthropic giving activities in firms without such connection are more valued by investors.

\section{AUTHOR INFORMATION}

Dr. Junrui Zhang is a professor of accounting in the School of Management at Xi'an Jiaotong University. His main research interests include corporate governance, accounting restatements, and earnings management, and he is currently leading the research project (No. 71172186) funded by National Natural Science Foundation of China, and the project funded by New Century Educational Talents Plan Of Education Ministry of PRC (No. NCET-07-0309). E-mail: zhangjr@mail.xjtu.edu.cn. Corresponding author.

Bei Yang is a doctorial student in accounting in the School of Management at Xi'an Jiaotong University. Her main research interests include corporate governance, corporate social responsibility, and auditing. E-mail: watermelon83619@163.com.

Dr. Fangjun Wang is an assistant professor of accounting in the School of Management at Xi'an Jiaotong University. His main research interests include corporate governance and corporate social responsibility, and he is currently directing the research project (No. 11CGL062) funded by National Social Science Foundation of China, and the research project of the Humanity and Social Science Youth Foundation of Ministry of Education of China (No. 10YJC630225). E-mail: wangfangjun@mail.xjtu.edu.cn.

Dr. Peng Wang an assistant professor of accounting in the Business School at Xi'an International Studies University. His main research interests include accounting conservatism and corporate social responsibility. E-mail: summeringw@163.com. 


\section{REFERENCES}

1. Adams, M., and P. Hardwick. (1998). An analysis of corporate donations: United Kingdom evidence. Journal of Management Studies, 35(5), 641-654.

2. Amato, L. H. and C. H. Amato. (2007). The effect of firm size and Industry on corporate giving. Journal of Business Ethics, 72, 229-241.

3. Atkinson, L. and J. Galaskiewicz. (1988). Stock ownership and company contributions to charity. Administrative Science Quarterly, 33, 82-100.

4. Bartkus, B. R., Morris, S.A., and Seifert, B. (2002). Governance and Corporate Philanthropy: Restraining Robin Hood? Business \& Society, 41(3): 319-344.

5. Boatsman, J. R. and S. Gupta. (1996). Taxes and corporate charity: empirical evidence from microlevel panel data. National Tax Journal, 49, 193-213.

6. Brammer, S. and A. Millington. (2006). Firm size, organizational visibility and corporate philanthropy: an empirical analysis. Business Ethics: A European Review, 15(1), 6-18.

7. Brown, W. O., E. Helland, and J. Smith. (2006). Corporate philanthropic practices. Journal of Corporate Finance, 12, 855-877.

8. Buchholtz, A. K., A. C. Amason, and M. A. Rutherford. (1999). Beyond resources: the mediating effects of top management discretion and values on corporate philanthropy, Business and Society, 38(2), 167-187.

9. Burt, R. S. (1983). Corporate Profits and Cooptation: Networks of Market Constraints and Directorate Ties in the American Economy. New York: Academic Press.

10. Carroll, R. and D. Joulfaian. (2005). Taxes and corporate giving to charity. Public Finance Review, 33(3), 300-317.

11. Clotfelter, C. T. (1985). Federal Tax Policy and Charitable Giving. Chicago: University of Chicago Press.

12. Cullinan,C., Dennis B., Robert F., and Dana L. (2008). Organization-harm vs. organization-gain ethical issues: an exploratory examination of the effects of organizational commitment. Journal of Business Ethics, 80 (2), 225-235.

13. Gao, Y. (2011). Philanthropic disaster relief giving as a response to institutional pressure: Evidence from China. Journal of Business Research, 64, 1377-1382.

14. Gardberg, N. A. and C. J. Fombrun. (2006). Corporate citizenship: creating intangible assets across institutional environments. Academy of Management Review, 31, 329-346.

15. Gul, F. A. (2006). Auditors' response to political connections and cronyism in Malaysia. Journal of Accounting Research, 44(5), 931-963.

16. Harbaugh, W. T. (1998). What do donations buy? A model of philanthropy based on prestige and warm glow. Journal of Public Economics, 67, 269-284.

17. Hess, D. and D. E Warren. (2008), The meaning and meaningfulness of corporate social initiatives. Business \& Society Review, 113(2), 163-197.

18. Hwang, D., P. Golemon, Y. Chen, T. Wang and W. Hung. (2009). Guanxi and business ethics in Confucian society today: an empirical case study in Taiwan. Journal of Business Ethics, 89, 235-250.

19. Liu, J., Y. Wang, and L. Wu. (2011). The effect of guanxi on audit quality in China. Journal of Business Ethics, 103(4), 621-638.

20. Navarro, P. (1988). Why Do Corporations Give to Charity? Journal of Business, 61(1), 65-93.

21. Neill, J. D., Stovall, O. S. (2005). Stakeholder salience and corporate social responsibility: evidence from three companies. Journal of Applied Business Research, 21(3), 71-78.

22. Oliver, C. (1991). Strategic responses to institutional processes. Academy of Management Review, 16, 145179.

23. Patten, D. (2008). Does the market value corporate philanthropy? Evidence from the response to the 2004 Tsunami Relief Effort. Journal of Business Ethics, 81(3), 599-607.

24. Porter, M. E. and M. R. Kramer. (2002). The competitive advantage of corporate philanthropy. Harvard Business Review, 80(12), 56-69.

25. Seifert B., S. A. Morris, and B. R. Bartkus. (2003). Comparing big givers and small givers: Financial correlates of corporate philanthropy. Journal of Business Ethics, 45(3), 195-211. 
26. Strahilevitz, M. (1999). The effect of product type and donation magnitude on willingness to pay more for a charity-linked brand. Journal of Consumer Psychology, 8(3), 215-241.

27. Strahilevitz M., and J. G. Myers. (1998). Donations to charity as purchase incentives: How well they work may depend on what you are trying to sell. Journal of Consumer Research, 24, 434-446.

28. Useem, M. (1988). Market and institutional factors in corporate contributions. California Management Review, 30(2), 77-88.

29. Wahab, E. A. A., M. M. Zain, K. James, and H. Haron. (2005). Institutional investors, political connection and audit quality in Malaysia. Accounting Research Journal, 22(2), 167-195.

30. Zhang, R., Z. Rezaee, and J. Zhu. (2009). Corporate philanthropic disaster response and ownership type: evidence from Chinese firms' response to the Sichuan earthquake. Journal of Business Ethics 91, 51-63.

31. Zhang, R., J. Zhu, H. Yue, and C. Zhu. (2010). Corporate philanthropic giving, advertising intensity and industry competition level. Journal of Business Ethics, 94, 39-52. 


\section{APPENDIX}

Taking the date of donation announcement as day 0 , we choose the 30-day estimation window, starting from Day -60 to Day -31, and the 2-day event window during Day 0 and Day +1 . Equally weighted return on market index is taken as the market return.

The market model is adopted to calculate abnormal return. Specifically, we firstly focus on the data in estimation window, and regress the actual daily returns on the market returns. With the regression coefficients estimated from Equation 1, we can estimate the "normal" returns among firms within the event window, as is shown in Equation 2. Then, abnormal return is the difference between the actual returns and the normal returns, which is shown in Equation 3. As is reflected in Equation 4, the aggregate abnormal return for stock $i$ is the sum of abnormal returns from day $T_{1}$ to day $T_{2}$.

$R_{\mathrm{it}}=\alpha_{\mathrm{i}}+\beta_{\mathrm{i}} * R_{\mathrm{mt}}+\varepsilon_{\mathrm{it}}$

Equation (1)

$\hat{R}_{\mathrm{it}}^{\wedge}=\hat{\alpha}_{\mathrm{it}}+\beta_{\mathrm{it}}^{\wedge} * R_{\mathrm{mt}}+\hat{\varepsilon}_{\mathrm{it}}$

Equation (2)

$A R_{\text {it }}=R_{\text {it }}-R_{\text {it }}^{\wedge}$

Equation (3)

$C A R_{i}=\sum_{t=T_{1}}^{T_{2}} A R_{i t}$

Equation (4)

where, $R_{\mathrm{it}}$ is the actual return of stock $i$ on day $t ; R_{\mathrm{it}}$ is the expected return of stock $i$ on day $t ; R_{m t}$ is the equally weighted market return on day $t ; A R_{\mathrm{it}}$ is the abnormal return of stock $i$ on Day $t ; C A R_{i}$ is the cumulative abnormal return of stock $i$ from day $T_{1}$ to $T_{2}$. 
NOTES 